\title{
Does Good Governance Matter FDI Inflow? Evidence from India
}

\author{
Hayat Khan ${ }^{*}$, Itbar Khan², M. Shabir Jan ${ }^{3}$, Arif Hussain Jandan ${ }^{4}$, Sher Khan ${ }^{5}$ \\ ${ }^{1}$ Business School of Guangxi University, Nanning, China \\ ${ }^{2}$ Department of Management Sciences, National University of Modern Languages, Islamabad, Pakistan \\ ${ }^{3}$ Department of Economics, Bacha Khan University, Charsadda, Pakistan \\ ${ }^{4}$ Department of Economics, Sindh Agriculture University, Sindh, Pakistan \\ ${ }^{5}$ School of Economics, Henan University, Kaifeng, China \\ Email: ^khiljihayat@gmail.com
}

How to cite this paper: Khan, H., Khan, I., Jan, M.S., Jandan, A.H. and Khan, S. (2019) Does Good Governance Matter FDI Inflow? Evidence from India. Modern Economy, 10, 1526-1538.

https://doi.org/10.4236/me.2019.106101

Received: April 15, 2019

Accepted: June 18, 2019

Published: June 21, 2019

Copyright $\odot 2019$ by author(s) and Scientific Research Publishing Inc. This work is licensed under the Creative Commons Attribution International License (CC BY 4.0).

http://creativecommons.org/licenses/by/4.0/

\begin{abstract}
Is there a relationship between governance and Foreign Direct Investment (FDI) adept in a presumed country? What is the importance of institutional set-up or governance in stimulating growth in a developing country? To answer this query, this study explores the distinction of good governance for FDI inflows in India for the time period of 14 years, i.e. from 1996 to 2012 by employing multiple regression models. Firstly, variance inflation factor (VIF) test shows that there is no perfect multicollinearity. Secondly, the empirical results evinced that institutional factors matter for huge FDI attraction in India. The paper evidence that India attract more FDI due to good governance, therefore it is acclaimed that government of India should take auxiliary steps to improve governance which can tempt more foreign investors and can help attain full employment, boost growth and can nurture per capita income.
\end{abstract}

\section{Keywords}

Governance Determinants, Foreign Direct Investment, Regression Analysis, Pearson Correlation

\section{Introduction}

Foreign Direct investment theaters a very protuberant role in economic growth and development in developing countries [4]. FDI has a critical significance, since of its competency and concrete paybacks to economic growth, employment creation, efficiency amplification; condensevenality and integration into 
global economy [1]. Lately, the deliberation on economic growth is riveted in the notion of good governance, which has an imperative aspect in the accurate functioning of market countries. Governments are infuriating to dexterities good atmosphere for FDI attraction which can give fortunate climate for multinational corporations through the perfection of political and economic institutions that rouse the admittance of FDI. However, there are numerous dynamics such as corruption, political instability and macroeconomic instability that negatively affect investment climate. A positive GDP growth has been found in India after liberalization of trade policies in India. Foreign direct investment generates employment, generating revenues in the form of tax and incomes and give financial stability to the government of a country. It is also a tool for the development of infrastructure, and makes linkages to the domestic firms for raw materials requirements and support financial system. FDI is required to raise per capita income, standard of living, improvement in GDP, growth and development of the country. On the other hand, the marginal productivity of capital in developed countries is high and the investors in developed countries seek high returns more than the developing countries. Hence there exist mutual doles in the flows of capital from one country to another in the form of foreign direct investment. Zidi and Ali (2016) have studied governance and foreign direct investment which states that governance impact FDI inflow positively in MENA countries [2]. Moreover, Azam and Lukman, L. (2008) [3] states that FDI is an important instrument for developing countries through which the developing countries can get access to the benefits of globalization. Similarly, (Hossain \& Rahman, 2017) [4] stated that governance indicators increase FDI inflow in developing countries. Furthermore, political stability, law and order situation (peaceful), mineral resources labor force and economic policies of the government help attract foreign investment [5]. Institutional factors influence FDI inflow positivity and differently than each other's while financial crises had negative impact on FDI inflow in developing countries [6]. Foreign direct investment depends on government policies, supportive infrastructure and transparent governance of the host country [7]. Furthermore, corruption affect FDI significantly, democracy, government stability, law and order, civil liberty and political rights have significant positive effects on FDI in flows [8]. On the other hand, (Asiedu, 2002) [9] had focused on policy reforms as the determinants of the developing countries for FDI inflows and found that the degree of openness to FDI and corporate rates are the determinants of FDI. Foreign direct investment plays a significant and positive role in economic growth of countries where the infrastructure has developed and trade policies are more liberal [10]. (Campos \& Kinoshita, 2002) [11] stated that there is significant positive impact of FDI on governance, if there is a transfer of technology to the host country. Increase in the foreign capital inflow can be improved through the government policy that can give incentives such as tariff reduction and tax concessions to the investors. MNCs are always seeking to make investment where the institutional environment is favorable [12]. In addition, foreign investors prefer to make their investments in countries where there 
is a transparent institutional framework characterized by a coherent politics. This study contributes to the existing literature by exploring the impact of governance indicators on FDI inflow in India. The current study will help to better explain the impact of governance on the FDI in India as there is only few or no study on this issue which has investigated the role of good governance on FDI inflow in developing country India. Hence, it's important to examine the effect of governance on the FDI inflow in Indian country. This study will provide appropriate policy for India that will help attract FDI in India and will also give basis for the governance indicators to be reformed and restructured in order to improve its impact on FDI inflow. This paper is structured as follows; Section 2 is composed of Literature on governance and FDI. Section 3 is composed of Methodology, variables and model specification. Section 4 shows the Estimation issues, analysis of data and interpretation of results, while Section 5 concludes the paper.

\section{Review of Literature}

To identify the role of quality institutions and governance as an energizer of FDI, it is imperious to find the role of governance factors on FDI inflows. Some of the recently studies have focused on the impact of institutional quality and governance role on FDI inflows [13] [14] [15]. The assumption is that good governance countries can attract more FDI. [16] [17] [18]. However weak governance polices cannot protect investments. Institutional variables such as corruption, political restrictions and protections of property rights are important factors of FDI inflows [19] [20]. Institutional quality positively and significantly influences foreign direct investment in developed countries while insignificant in developing countries [21].Institutions play a very important role in attracting foreign direct investment and exert long run impact on FDI inflows in Pakistan [22]. On the other hand, IFRS adoption doesn't affect FDI inflow in developing countries, however IFRS adoption and quality institutions countries that adopted the IFRS experience better FDI inflows in the presence of institutional quality [23]. (Alfaro \& Chauvin, 2016) [24] Have also examined the impact of FDI on economic development of host countries and role of local financial markets in facilitating potential benefits. They have used host country perspective rather than firm perspective rich firm-level on MNCs and have highlighted financial condition effect on FDI in host countries related to capital inflows, shaping foreign firms operation, and arbitrate the level of productivity spillovers from FDI to local firms. Similarly, (Manasseh, Mathew, \& Ogbuabor, 2017) [25] have examined the relationship between institutional quality and stock market development. They have measured institutional quality with control of corruption, democratic accountability and bureaucratic quality. Furthermore (NGUYEN \& CAO, 2015) [26] have found positive impact of institutional quality on Foreign Direct Investment (FDI) Inflows in Vietnam. They stated that three components of institutional quality namely political stability, absence of violence, regulatory quality and control of corruption are essential factors of attracting FDI in Vietnam. On the other hand (Nondo, Kahsai, \& Hailu, 2016) [27] have 
studied the impact of institutional quality on FDI inflow in SSA countries. There results contradict with other studies because their study shows that there is no significant relationship between FDI and institutional quality. (Aidt, Dutta, \& Sena, 2008) [28] stated that if there is an accountability of the politicians in a country so it will reduce the corruption and will leads to economic growth. (Moussa, Çaha, \& Karagöz, 2016) [29] have studied economic freedom and FDI and have found positive impact of economic freedom on FDI. Beside this (Hugill \& Siegel, 2014) [30] have studied the importance of corporate governance their result suggest that over recent years firms in emerging economics had more abilities to rise above home-country peer firms in corporate governance rating than has been previously suggested. (Ullah \& Khan, 2017) [31] Have studied institutional quality and FDI in south Asian countries and have that institutional factors play an important role in attracting FDI inflows in the ASEAN region as compared to Central Asian and SAARC regions. Alfaro and Chauvin (2017) [32] have analyzed the interactions between FDI inflows and financial sector development in Central and Eastern European Union countries and have found that that there is no cointegrating relationship among FDI inflows, investments of foreign portfolio, and the development of financial sectors, but there is a one-way causality from development of financial sectors to FDI inflows over the short run. (Rei \& Bhattacharya, 2008) [33] observed the effect of tax on Greece that the inability of collecting tax will encourage the underground economy that weakens the government ability to stabilize the economy. (Globerman, Shapiro, \& Tang, 2006) [34] examined the impact of corruption and the role of governance on foreign capital inflow as well outflow. (Boschini, Pettersson, \& Roine, 2007) [35] stated that most of the time the natural resources brings conflicts and issues to the country and have negative impact on the country, but these negative impact can be tum into positive impact through solid institutional quality. (Hout, 2007) [36] reported that Bad governance is connected with corruption, distort the government budgets inequitable growth and development of the country and because of corruption the people has trust in authorities. Fan et al. (2009) [37] investigated the role of governance and have found that governance is the broader measure of corruption and good governance enhance the level of investment and encourage FDI because of the profitability in the business environment of the country.

\section{Materials and Methods}

The purpose of this study is to investigate the impact of governance on FDI in India. Population for the study is India taken as to find the significance of governance on FDI. Gretel software has used for analysis purpose to the data collected from the world governance indicator published by World Bank for the period of 1996 to 2012. This study use Ordinary least square method for estimating the parameters or hypothesis of the model. The multiple regression model has used because the study has to find the relationship of multiple independent variables on the dependent variables. The Pearson product moment has 
used to measure the liner relationship between two variables. It measures that the correlation between the dependent variable and the independent variable is linear and it is negative relationship or positive.

\section{Statistical Model}

The below statistical model has been used for the analysis purposes. The variable of the model and its constriction are adopted from the study of the Kaufmann presented in 2007

$$
\mathrm{FDI}=\alpha+\beta_{1} \mathrm{VA}+\beta_{2} \mathrm{PV}+\beta_{3} \mathrm{GE}+\beta_{4} \mathrm{RQ}+\beta_{5} \mathrm{RL}+\beta_{6} \mathrm{CC}+\mathrm{Z}+\mu
$$

The following are the independent and control variables for analysis. Voice and Accountability (VA), Political Stability and Absence of Violence/f terrorism (PV), Government Effectiveness (GE), Regulatory Quality (R Q), Rule of Law $(\mathrm{RL})$ are the main variables and Exchange Rate (ER), Interest Rate (Inst rate), Gross Domestic Product (GDP) and Inflation are control variables. $Z$ is the vector of control variables which potentially affect our dependent variables.

\subsection{Analysis and Findings}

Reliability Test for Data Consistency.

Figure 1 shows that cronbach's alpha is 0.5 which is greater than 0.05 , there exists internal consistency in the construct of the variable GI.

\subsection{Descriptive Statistics}

Table 1 shows the descriptive statistics for India. The minimum value of VA is 0.26 the maximum value is 0.45 the mean value is 0.37 while the standard

\begin{tabular}{|c|c|}
\hline Cronbach's Alpha & No. of Items \\
\hline 0.85 & 6 \\
\hline
\end{tabular}

Figure 1. Reliability test for data internal consistency.

Table 1. Descriptive statistics.

\begin{tabular}{ccccc}
\hline & Min & Max & Mean & Std.D \\
\hline Year & 1996 & 2012 & 2004.00 & 5.050 \\
VA & 0.260 & 0.450 & 0.3711 & 0.0637 \\
PS & -1.53 & -0.91 & -1.145 & 0.163 \\
GE & -0.180 & 0.110 & -0.067 & 0.0694 \\
RQ & -0.470 & -0.160 & -0.339 & 0.0961 \\
RL & -0.110 & 0.290 & 0.122 & 0.1425 \\
CC & -0.570 & -0.280 & -0.408 & 0.0882 \\
GDP & 3.24 & 10.55 & 6.551 & 2.550 \\
INST RATE & -0.48 & 9.40 & 5.721 & 2.675 \\
ER & 35.43 & 53.44 & 44.541 & 4.360 \\
INF & 3.68 & 13.23 & 7.050 & 3.110 \\
FDI & 0.47 & 3.55 & 1.360 & 0.8413 \\
VALID N (Listwise) & & & &
\end{tabular}


deviation is 0.06 . The minimum value of the PS of is -1.53 maximum value is -0.91 the Mean value is -1.14 while the standard deviation is 0.16 . The minimum value of the GE is -0.18 the maximum value is 0.11 the mean value is -0.06 while the standard deviation is 0.061 . The minimum value of RQ is -0.47 the maximum value is -0.16 the mean value is -0.33 while the standard deviation is 0.96 . The minimum value of the $R L$ is -0.11 , maximum value is.29 the mean value is 0.12 while the standard deviation is 0.14 . The Minimum value of CC IS -0.57 , maximum value is -0.28 the mean value is -0.41 while the standard deviation is 0.08 .

The minimum value of the GDP is 3.24 , maximum value is 10.55 the mean value is 6.55 while the standard deviation is 2.5 . The minimum value of interest rate is -0.48 . Maximum value is 9.4 the mean value is 5.7 while the standard deviation is 2.67. The minimum value of the ER is 35.43, maximum value is 53.44 the mean value is 44.54 while the standard deviation is 4.36 . The mean value of the Inf is 3.68, maximum value is 13.23 the mean value is 7.0 while the standard deviation is 3 . The minimum value of the FDI is 0.47 the maximum value of FDI is 3.55 the Mean value is 1.36 while the standard deviation is 0.84 .

\subsection{Pearson Correlation Analysis}

Table 2 shows the correlation between FDI and the independent variables that has been taken. In the model the Pearson correlation has been used to find the linear association between the FDI and the independent variables. In the below table there exists a positive correlation between FDI and VA which is $60 \%$ indicates that if in a country voice and accountability (VA) is high the FDI inflow toward s the country will also high and if the VA in a country is low the FDI

Table 2. Pearson correlation analysis.

\begin{tabular}{cccccccc}
\hline & FDI & VA & PS & GE & RQ & ROL & CC \\
\hline FDI & 1 & & & & & & \\
VA & 0.606 & 1 & & & & & \\
PS & -0.167 & -0.233 & 1 & & & & \\
GE & 0.473 & 0.659 & -0.184 & 1 & & & \\
RQ & 0.131 & -0.203 & 0.242 & 0.084 & 1 & & \\
ROL & -0.440 & -0.504 & 0.658 & -0.203 & 0.298 & 1 & \\
CC & -0.089 & -0.275 & 0.394 & -0.014 & 0.297 & 0.817 & 1 \\
Int rate & -0.437 & -0.458 & 0.323 & -0.295 & 0.285 & 0.687 & 0.531 \\
ER & 0.279 & 0.092 & -0.609 & -0.273 & 0.164 & 0.647 & -0.44 \\
GDP & 0.230 & 0.376 & -0.190 & 0.069 & 0.108 & -0.040 & 0.37 \\
INF & 0.326 & 0.282 & -0.101 & 0.314 & -0.429 & -0.231 & -0.09 \\
\hline
\end{tabular}


inflow will be also low so there is a positive association among the dependent variable FDI and the independent variable VA.

In Table 2, there is a negative relationship between FDI inflow and PS in a country that is $-16.7 \%$ that political stability and absence of violence (PS) has an inverse impact on FDI inflow i.e. if the government is instable and if there is violence in a country it will inversely effect the FDI as well the economy of the country. In the table there exists correlation between FDI and GE which is $47.3 \%$ that if the government is able to implement sound economic policies can bring a positive impact of the FDI inflow towards the country. In the table there also exists a positive correlation between FDI and RQ that if the government makes sound policies can bring a positive change in the FDI inflow by $13.1 \%$. In the table there exists a negative or inverse relationship between FDI and RL which is $-44 \%$ that a weak rule of laws in a country can inversely effect the FDI inflow i.e. if the country rule of law is highly weak the FDI inflow will low. Corruption has a negative association with the FDI inflow which is shown by the table that is $-8.9 \%$ that corruption can bring effect on the FDI inflow. In the table the GDP shows a positive impact on the FDI inflow that is $23 \%$ that if the country GDP is high the FDI inflow will also high. In the table there is a negative relationship can be seen among the FDI and interest rate (inst rate) which is $-43.7 \%$ indicates that if the rate of interest in a county will high the FDI will low and if the rate of interest in a country will the FDI will high. In the table there exists a positive relationship between FDI and ER. In the table there exists a positive correlation between FDI and inflation (Inf) which is $32.6 \%$ that inflation can positively attract the FDI inflow i.e. The inflation rate in a country is high the FDI inflow will also high and if the rate of inflation in a country is low the FDI inflow will also low.

\section{Regression Analysis}

Table 3 shows the regression analysis. The table shows the coefficient of the VA with the FDI is 28.88 with $\mathrm{t}$-calculated value of 5.027 and P-calculated value of 0.8850 the coefficient is significant as the $t$-calculated value is greater than 2 value of thumb value and greater than P-value critical value. So the coefficient is significant and there exists a significant relationship between FDI and VA that a change occurs in VA can bring changes in FDI. The coefficient of PS with FDI is 2.311 with the $t$-calculated value of 2.44 and $\mathrm{P}$-calculated value of 0.058 . The coefficient is significant, the $\mathrm{t}$-calculated value is greater than the $\mathrm{t}$-tabulated value. So the coefficient is significant and changes occurs in PS bring changes in FDI of the country. The coefficient of GE with FDI is 1.36 with the calculated value 0.047 and $\mathrm{P}$-calculated value is 0.065 the coefficient is insignificant as the $\mathrm{t}$-calculated value is less than the $\mathrm{t}$-tabulated value indicates that there is insignificant relationship between FDI and GE, that any changes in GE will not bring any significant changes in the FDI in India. The coefficient of RQ with FDI is 4.26 with the calculated value 2.914 and P-value 0.0332 , the coefficient is significant as the $t$-calculated value is greater than the $t$-tabulated indicates that the 
Table 3. Regression analysis.

\begin{tabular}{ccccc}
\hline & \multicolumn{3}{c}{ Regression OLS } \\
\hline Variable & Coefficient & Std. error & t-value & p-value \\
\hline Constant & 0.391 & 2.477 & 0.158 & 0.8805 \\
Va & 28.887 & 5.745 & 5.027 & 0.004 \\
Ps & 2.311 & 0.947 & 2.440 & 0.058 \\
Ge & 1.368 & 2.888 & 0.473 & 0.655 \\
Rol & 4.043 & 1.306 & 3.095 & 0.027 \\
CC & 11.282 & 2.709 & 4.163 & 0.008 \\
Instrate & 0.079 & 0.069 & $\mathrm{U} 43$ & 0.304 \\
ER & 0.017 & 0.054 & 0.324 & 0.758 \\
GDP & 0.242 & 0.063 & 3.827 & 0.012 \\
RQ & 4.276 & 1.467 & 2.914 & 0.033 \\
INF & 0.356 & 0.084 & 4.223 & 0.008 \\
\hline
\end{tabular}

R-Squared: 0.617187.

coefficient of RQ, that the RQ have significant effect on FDI. The coefficient of the RL with FDI is 4.04 with the $\mathrm{t}$-calculated value of 3.095 and the P-calculated value of 0.0270 . The $t$-calculated value is greater than the $t$-tabulated value indicates that the RL has significant impact on the FDI and if there changes occurs in the RL there will changes occurs in FDI in India. The coefficient of corruption (CC) with FDI is 11.28 and the $t$-calculated value is 4.163 and P-calculated value 0.0088 , the $t$-calculated value is greater than the value of the $t$-tabulated indicates that there is significant relationship between FDI and CC in India. In the table, the coefficient of GDP with FDI is 0.24 with the $t$-calculated value of 3.827 and P-calculated value 0.0123 .

Indicates that there is significant relationship between FDI and GDP in India, that the higher the GDP will have brought no influence on FDI inflow in India. In the table the coefficient of the interest rate (instrate) with the FDI is 0.079 with the $t$-calculated value of 0.114 and with the P-calculated value of 0.3 indicates that the relationship between FDI and inst is insignificant that, and increase or decrease in the interest rate will bring no changes in FDI inflow to the country India. The coefficient of the ER with the FDI is 0.017 with the tabulated value of 0.32 and the P-calculated value 0.76 indicates that the relationship between FDI inflow and ER is insignificant in the case of India that the $t$-calculated value is less than the t-tabulated value 2.10 . So the insignificant relationship shows that if ER increases or decrease, it have no significant impact on FDI inflow in India. In the table the rate of inflation (Inf) coefficient with the FDI is 0.35 with the t-calculated value of 4.233 and P-calculated value of 0.0083 indicates that there exists significant relationship between FDI and Instrate because in the table the t-calculated value is less than the t-tabulated, indicates the significant relationship. The coefficient of governance indicator GI with FDI is 5.09 
and t-calculated value of 5.09 and P-calculated value of 0.000 indicates that the relationship between FDI and GI is insignificant because the $t$-calculated value is less than the t-tabulated value shows the insignificant relationship between FDI and GI in the case of India. F-test shows the overall significance of the model. In our case the value of F-calculated is 40.74 is more than the critical value and its $\mathrm{P}$-value is 0.000366 lower than critical value so thus the overall model is statistically significant. R-square of the model suggested the explanatory power of the model. In our case the value is 0.61 which suggested that $61 \%$ changes in the value of FDI is explain by the considered independent variables.

\begin{tabular}{cc}
\hline \multicolumn{2}{c}{ Variance Inflation factors } \\
\hline & Minimum possible value $=$ I.O \\
\hline $\mathrm{Va}$ & Values $>10.0$ may indicate a collinarity problem \\
$\mathrm{Ps}$ & 7.009 \\
$\mathrm{Ge}$ & 4.305 \\
$\mathrm{Rq}$ & 3.000 \\
$\mathrm{Rl}$ & 3.937 \\
$\mathrm{Cc}$ & 5.182 \\
$\mathrm{Gdp}$ & 8.714 \\
Instratc & 4.618 \\
Er & 4.802 \\
Inf & 2.025 \\
\hline
\end{tabular}

\section{Governance Index of India}

Table 4 shows the regression analysis where value of the GI is significant: that there is an impact of the GI on the FDI as the coefficient of GI with FDI is 4.87 and the $t$-calculated value is 1.92 and the $\mathrm{P}$-value 0.080 . Its indicates the positive relationship of GI with FDI. In the other variable the interest rate is insignificant the value of the ER is significant as the coefficient of the ER is 0.54 with the T-calculated value is 2.164 and $\mathrm{P}$-value is 0.053 . In the table the coefficient of the GDP with FDI is 0.035 with the t-calculated value is 0.62 and P-value is 0.544 , the relationship is insignificant with FDI. The relationship between inflation and FDI is insignificant as the $t$-calculated value is greater than $t$-tabulated value and $\mathrm{P}$-value is greater than 0.05 . F-test shows the overall significance of the model. In our case the value of $\mathrm{F}$ calculated is more than the critical value and its $\mathrm{P}$-value is lower than critical value so thus the overall model is statistically significant. $\mathrm{R}$-square of the model suggested the explanatory power of the model. In our case the value is 0.36 which suggested that $36 \%$ changes in the value of FDI is explain by the considered independent variables but the high value of R-square shows that multicollinearity exists in some of the variables. The value of the F-test is 8.89 which is greater than the $\mathrm{F}$ value 4 . So it indicates that the overall model is 
Table 4. Governance index of India.

\begin{tabular}{ccccc}
\hline \multicolumn{4}{c}{ Dependent variables } \\
\hline coefficient & std.error & t-ratio & p-value \\
\hline const & 0.114 & 2.339 & 0.048 & 0.961 \\
gj & 4.877 & 2.533 & 1.925 & $0.080^{*}$ \\
gdp & 0.035 & 0.056 & 0.625 & 0.544 \\
iostrate & 0.102 & 0.091 & 1.120 & 0.286 \\
er & 0.054 & 0.025 & 2.164 & $0.053{ }^{*}$ \\
iof & 0.061 & 0.093 & 0.655 & 0.525 \\
Mean dependent var & 1.360 & S.D. dependentvar & 0.841 \\
Sum squared resid & 7.276 & S.E. ofregression & 0.813 \\
R-squared & 0.357 & AdjustedR-squared & 0.065 \\
F(S, 11) & 8.895 & \multicolumn{2}{c}{ P-value(F) } & 0.001 \\
Log-likelihood & 16.908 & Akaikecriterion & 45.817 \\
Schwa1-z. criterion & 50.8 & Hannan-Quinn & 46.314 \\
Rho & 0 & Durbin-Watson & 1.227 \\
\hline
\end{tabular}

significant and the governance has impact of the FDI of the country in the case of India.

From the above empirical results it is proved that the governance indicators such as VA, PS, RQ, RL and CC has a significant impact on the FDI inflow that a change occurs in these governance indicators can bring significant change on the FDI inflow. So if the government of India improves the governance it can attracts more and more foreign investors to the country and by doing so they can achieve full employment, high growth and development and they can raise the per capita income of the people of the country.

\section{Conclusion}

The countries particularly the developing countries are facing shortage of capital because their marginal propensity to consume is much greater than marginal propensity to save. So in this situation mostly they depend on foreign investment to increase the level of employment to achieve high level of growth and development. So in this situation, the foreign investment becomes more and more necessary for the country. This paper investigates the impact of governance on FDI inflow in India. The data had taken for a period 1996 to 2012. VIF test was applied and no perfect multicollinearity was found among the independent variables. The multiple regression models were applied and empirical results proved that governance indicators such as VA, PS, RQ, RL and CC has significant impact on FDI inflow that a change occurs in these governance can bring significant change in FDI inflow. This paper suggests that government of India should improve governance so it can attract more and more foreign investors to the 
county and by doing so they can achieve full employment, high growth and development and they can raise per capita income of the people of the country.

\section{Conflicts of Interest}

The authors declare no conflicts of interest regarding the publication of this paper.

\section{References}

[1] Masipa, T.S. (2018) The Relationship between Foreign Direct Investment and Economic Growth in South Africa: Vector Error Correction Analysis. Acta Commercii, 18, 1-8. https://doi.org/10.4102/ac.v18i1.466

[2] Zidi and Ali (2016) Foreign Direct Investment (FDI) and Governance: The Case of MENA. Journal of Research in Business, Economics and Management, 5, 598-608.

[3] Azam and Lukman, L. (2008) Determinants of Foreign Direct Investment in India, Indonesia and Pakistan: A Quantitative Approach. Journal of International Business Management, 4, 31-44.

[4] Hossain and Rahman (2017) Does Governance Facilitate Foreign Direct Investment in Developing Countries? International Journal of Economics and Financial Issues, 7, 164-177.

[5] Aqeel, A. and Muhammad, N. (2004) The Determinants of Foreign Direct Investment in Pakistan. The Pakistan Development Review, 43, 651-664. https://doi.org/10.30541/v43i4IIpp.651-664

[6] Kurul, Z. and Yalta, A.Y. (2017) Relationship between Institutional Factors and FDI Flows in Developing Countries: New Evidence from Dynamic Panel Estimation. Economies, 5, 17. https://doi.org/10.3390/economies5020017

[7] Dunning, J.H. and Lundan, S.M. (2008) Multinational Enterprises and the Global Economy. Edward Elgar Publishing, Cheltenham.

[8] Hussain, S. and Malik, S. (2011) Inflation and Economic Growth: Evidence from Pakistan. International Journal of Economics and Finance, 3, 262-276. https://doi.org/10.5539/ijef.v3n5p262

[9] Asiedu, E. and Lienn, D. (2002) Democracy, Foreign Direct Investment, and Natural Resources. Journal of International Economics, 84, 99-111. https://doi.org/10.1016/j.jinteco.2010.12.001

[10] Zhang, K.H. (2001) How Does Foreign Direct Investment Affect Economic Growth in China? Economics of Transition, 9, 679-693. https://doi.org/10.1111/1468-0351.00095

[11] Campos, N.F. and Kinoshita, Y. (2002) Foreign Direct Investment as Technology Transferred: Some Panel Evidence from the Transition Economies. The Manchester School, 70, 398-419. https://doi.org/10.1111/1467-9957.00309

[12] Zaidi, H.H. (2004) Snags in the Inflow of FDI. Down-Business 09 August, 2004. http://www.down.com/2004/08/09/ebr7htm

[13] Ali, F.A., Fiess, N. and MacDonald, R. (2010) Do Institutions Matter for Foreign Direct Investment? Open Economies Review, 21, 201-219. https://doi.org/10.1007/s11079-010-9170-4

[14] B. G., Le, Q.V. and Rishi, M. (2012) Foreign Direct Investment and Institutional Quality: Some Empirical Evidence. International Review of Financial Analysis, 21, 81-89. https://doi.org/10.1016/j.irfa.2011.10.001 
[15] Wei, S.-J. and Shleifer, A. (2000) Local Corruption and Global Capital Flows. Brookings Papers on Economic Activity, 2000, 303-354. https://doi.org/10.1353/eca.2000.0021

[16] Globerman, S. and Shapiro, D. (2002) Global Foreign Direct Investment Flows: The Role of Governance Infrastructure. World Development, 30, 1899-1919. https://doi.org/10.1016/S0305-750X(02)00110-9

[17] Globerman, S., Shapiro, D. and Tang, Y. (2004) Governance and Foreign Direct Investment in Emerging and Transition European Countries.

[18] La Porta, R., Lopez-de-Silanes, F. and Shleifer, A. (1999) Corporate Ownership around the World. The Journal of Finance, 54, 471-517. https://doi.org/10.1111/0022-1082.00115

[19] Bergara, M.E., Henisz, W.J. and Spiller, P.T. (1998) Political Institutions and Electric Utility Investment: A Cross-Nation Analysis. California Management Review, 40, 18-35. https://doi.org/10.2307/41165931

[20] Richards, D.C. and Nwankwo, S. (2005) Reforming the Legal Environment of Business in Sub-Saharan Africa: Moderating Effects on Foreign Direct Investment. Managerial Law, 47, 154-163. https://doi.org/10.1108/03090550510771179

[21] Peres, M., Ameer, W. and Xu, H. (2018) The Impact of Institutional Quality on Foreign Direct Investment Inflows: Evidence for Developed and Developing Countries. Economic Research-Ekonomska istraživanja, 31, 626-644. https://doi.org/10.1080/1331677X.2018.1438906

[22] Ahmad, M.H., Ahmed, Q.M. and Atiq, Z. (2018) The Impact of Quality of Institutions on Sectoral FDI: Evidence from Pakistan. Foreign Trade Review, 53, 174-188. https://doi.org/10.1177/0015732517734757

[23] Owusu, et al. (2017) IFRS Adoption, Institutional Quality and Foreign Direct Investment Inflows: A Dynamic Panel Analysis. Asian Journal of Business and Accounting, 10, 43-75.

[24] Alfaro, L. and Chauvin, J. (2016) Foreign Direct Investment, Finance, and Economic Development.

[25] Manasseh, C.O., Mathew, T.E. and Ogbuabor, J.E. (2017) Investigating the Nexus between Institutional Quality and Stock Market Development in Nigeria: An Autoregressive Distributed Lag (ARDL) Approach. African Development Review, 29, 272-292. https://doi.org/10.1111/1467-8268.12256

[26] Nguyen, T.V.H. and Cao, T.H.V. (2015) The Impact of Institutional Quality on Foreign Direct Investment (FDI) Inflows to Vietnam.

[27] Nondo, C., Kahsai, M.S. and Hailu, Y.G. (2016) Does Institutional Quality Matter in Foreign Direct Investment? Evidence from Sub-Saharan African Countries. African Journal of Economic and Sustainable Development, 5, 12-30. https://doi.org/10.1504/AJESD.2016.074441

[28] Aidt, T., Dutta, J. and Sena, V. (2008) Governance Regimes, Corruption and Growth: Theory and Evidence. Journal of Comparative Economics, 36, 195-220. https://doi.org/10.1016/j.jce.2007.11.004

[29] Moussa, et al. (2016) Review of Economic Freedom Impact on FDI: New Evidence from Fragile and Conflict Countries. Procedia Economics and Finance, 38, 163-173. https://doi.org/10.1016/S2212-5671(16)30187-3

[30] Andrea Hugill, J.S. (2014) Which Does More to Determine the Quality of Corporate Governance in Emerging Economies, Firms or Countries? Harvard Business School, Boston, 1-54. 
[31] Ullah and khan (2017) Institutional Quality and Foreign Direct Investment Inflows: Evidence from Asian Countries. Journal of Economic Studies, 44, 1030-1050. https://doi.org/10.1108/JES-10-2016-0215

[32] Alfaro and Chauvin (2017) Foreign Direct Investment, Finance, and Economic Development, Chapter for Encyclopedia of International Economics and Global Trade. $1-32$.

[33] Rei, D. and Bhattacharya, M. (2008) The Impact of Institutions and Policy on Informal Economy in Developing Countries: An Econometric Exploration.

[34] Globernnan, et al. (2006) Global Foreign Direct Investment Flows: The Role of Governance Infrastructure. World Development, 30, 1899-1919. https://doi.org/10.1016/S0305-750X(02)00110-9

[35] Pettersson, J. and Roine, J. (2007) Resource Curse or Not: A Question of Bosch Appropriability. Scandinavian Journal of Economics, 109, 593-617. https://doi.org/10.1111/j.1467-9442.2007.00509.x

[36] Hout, W. (2007) The Politics of Aid Selectivity: Good Governance Criteria in World Bank, US and Dutch Development Assistance. Routledge, Abingdon-on-Thames. https://doi.org/10.4324/9780203945780

[37] Fan, et al. (2009) Institutions and Foreign Direct Investment: China vs. the Rest of the World. World Development, 37, 852-865.

https://doi.org/10.1016/j.worlddev.2008.07.016 